\title{
埼玉県本庄市における細の担保倉庫の発生とその機能 \\ 旧本庄商業銀行棟瓦倉庫に関する調査・研究報告 \\ APPEARANCE AND FUNCTION OF THE WAREHOUSE FOR COCOON AS COLLATERAL IN HONJO, SAITAMA
}

A study of the old brick warehouse of the commercial bank of Honjo

\author{
本橋 仁*, 中谷礼仁** \\ Jin MOTOHASHI and Norihito NAKATANI
}

\begin{abstract}
This paper reports the basic research and the background of the Old Brick Warehouse of the Commercial Bank of Honjo, completed in 1896, Honjo city, Saitama prefecture. This paper, is the first of the follow-through repots on this architecture.

By this paper, it could be said that this brick warehouse shows a stage of development in silk industry under the promotion of new industry in Japan. These banks which support the small and mid-sized companies of the silk industry has vitalized the cocoon market, enriched the silk-raising farmers in Honjo and Maebashi city and so forth. These private banks were keys to the regional economy and so this possibly could be the reason it had enough facility investments.
\end{abstract}

\section{Keywords : Meiji era, Silk industry, Brick work, Warehouse, bank} 明治，絹産業，煉瓦造，倉庫，銀行

\section{1. はじめに}

\section{1. 調査・研究の背景}

本稿が対象とする建造物は、旧本庄商業銀行煉瓦倉庫（所在地： 本庄市銀座 1-5-16 以下、本庄煉瓦倉庫）である。2011 年まで洋菓 子店として利用されていたが、その後本庄市の近代化の歴史におい て重要な建造物であるとして、本庄市が取得し、現在に至る。 2011 年より早稲田大学理工学術院建築学科では、本庄煉瓦倉庫の 実測調查、ならびに耐震調查に取り組んできた出1)。それら調查によ り、これまで不明であった竣工年や施工者、設計者などが、今回は じめて明らかとなった望2)。本稿では、本煉瓦倉庫の当初用途であっ た銀行の担保とした蕾を保管する倉庫であったという性格から、そ の機能を充足させる建築計画の特徵を論じる。

なお、同倉庫については周辺地域の他類似遺構との比較調查を通 して、明治中期煉瓦造建造物の技術面における特異性についても明 らかとなった。これらは、次稿に詳細な報告をおこなう。

\section{2. 本建造物に関する既往研究}

本庄煉瓦倉庫は、明治期の文化財として扱われてきたが、その根 拠は確たるものではなかった。確認できうる最も古い記事は、1979 年の「埼玉県明治建造物緊急調查報告書」》である。同調查は、埼玉
県が主導しておこなわれた、1971 年から行われた調査報告である。 一方、日本建築学会が主導し、1963 年に発表された「全国明治洋風

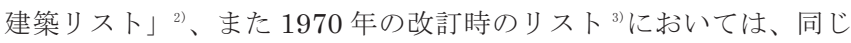
く本庄市の建造物である「本庄警察署（現在の本庄市立歴史民俗資 料館)」(明治 16 年竣工)は収録されているが、本庄煉瓦倉庫は収録 が確認できないため、1970 年頃を境に、文化財としての認知が進ん だものと考えられる。

なお、前述の報告書において、本庄煉瓦倉庫は竣工年が「明治 35 年」、設計者・施工者ともに不明とされてきた。また、建築学会の「総

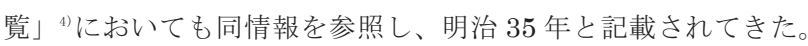

その後、竕工年は「明治 27 年頃」と改められ、1997 年に国登録 有形文化財として登録された際も明治 27 年頃の建設とされてきた。 しかし、今回の早稲田大学の文献調查により、新資料が発見され、 これまでの情報は不正確であったこと、またその施工者・設計者が 確認寸ることができた。また本庄煉瓦倉庫の、近年の研究として太 田徹氏の群馬県の煉瓦造倉庫を対象とした一連の研究 ${ }^{5}$ において、 上毛倉庫株式会社 $2 \cdot 3$ 号倉庫との比較において、本庄煉瓦倉庫が 取り上げられている。同研究においては、両煉瓦造倉庫の当初用途 の類似性から、その考察を行ったものである。

* 早稲田大学理工学術院創造理工学部建築学科 助手 . 修士 (工学) 


\section{2. 旧本庄商業銀行煉瓦倉庫の建築概要}

まず本庄煉瓦倉庫の基礎情報について述べる。なお、以下の内容

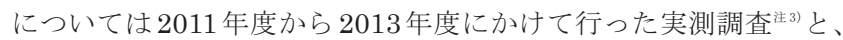
文献調查を基にしている。

\section{1. 竣工年・設計者等の確定}

\section{(『清水方建築家屋撮影』より)}

調査の途上で、本庄煉瓦倉庫の登場する、確認できうる最も古い 資料として、「明治三十三年十二月製『清水方建築家屋撮影』」第 2 巻注1)が確認できた。これは明治 33(1900)年 12 月に現在の清水建設 の前身である「清水店」注5)が製作した竣工建物の写真帳である。 写真帳において、「本庄商業銀行倉庫新築工事」(Fig. 1 及び 2$)$ と して、施工者や施工期間等の情報とともに、写真・平面図が掲載さ れている。これらの情報より、これまで不明であった施工者・設計 者、また、前述のように不明瞭であった竣工年を確定することがで きた。

\subsection{1. 施工期間・竣工年}

写真帳より、以下のとおり判明した。

・起工 明治ニ十九年ニ月ニ十八日

\section{・落成 同公旦}

なおこれは、以下にも述べる同用途の上毛倉庫株式会社倉庫が、 明治 29 年 1 月 15 日起工〜同年 6 月 30 日落成であるという事実洋 6 より、ほぼ施工期間をおなじくして建てられている。

\subsection{2. 設計者の確定}

写真帳より、施工者は「清水店」であると判明した。また、担当 した技師は、清水店の岡本銺太郎(慶応 3(1867)年-大正 7(1918)年)・ 清水釷吉(慶応 3(1867)年-昭和 23(1948)年)であった。その後、清水 釘吉は、第三代技師長(在任: 明治 27 年 2 月〜同年 10 月)をつとめ、 その後、合資会社清水組改組以降、初代社長となる人物である。ま た、岡本銺太郎も四代技師長(在任：明治 34(1901)年 6 月～大正 2(1913)年 6 月)を、清水の後をつぎ務めた人物である。岡本は、清 水店における二十余年の職務の中で、和洋各種の建築を設計したが、 なかでも前半は紡績工場をはじめとする工場建築で腕をふるい、後 半では和洋住宅の改良に独自の手腕を示した。また、欧米の新施工
技術の導入にも力を入れていた。

また補足事項ではあるが、同写真帳には前橋市に現存する上毛倉 庫株式会社二号三号倉庫(以下、上毛倉庫)も掲載されていた。それに より同煉瓦倉庫も同様に清水店であり、また設計は本庄煉瓦倉庫の 設計者である岡本銺太郎によるものであることが判明した。これま で既往研究においては、『上毛倉庫七十年誌』(上毛倉庫. 1966.）「゚ おける、上毛倉庫設計の際に国立第三十九銀行倉庫(明治 22(1889) 年竣工)を模範としたとされる情報をもとに、清水店による施工の可 能性にとどまっていたが、ここで併せて報告しておく。

\section{3. 建築規模 ·構造 $\cdot$ 計画等 (実測調査より)}

\subsection{1. 建築規模 $\cdot$ 構造}

本庄煉瓦倉庫の敷地には、現在、同倉庫と土蔵の二棟からなる。 本稿で主に扱う煉瓦倉庫の概要は以下のとおりである。

- 煉瓦造（床組・小屋組：木造）、2 階建て、栈瓦葺き

煉瓦はイギリス積みで積まれている。なお、北面と西面の腰部の み焼過煉瓦により表面が覆われている。

- 桁行 (南北) $36.342 \mathrm{~m} \times$ 梁間 (東西) $9.080 \mathrm{~m}$ (119.9 尺 $\times 30.0$ 尺)

- 建築面積 $330.721 \mathrm{~m}^{2}$

- 延べ床面積 (1階 $288.239 \mathrm{~m}^{2} 2$ 階 $300.127 \mathrm{~m}^{2}$ )

\subsection{2. 建築計画}

倉庫には現状 4 箇所の出入口がある。建設当初の出入口は、西側・ 元出入口を含めた、西側 2 箇所のみであり、西側・店舗入口 2 は、 当初の開口部を改修し利用している。

また、倉庫妻側・平側、 $1 \cdot 2$ 階には、問錠付両開防火鉄扉をつけ た空が等間隔で設けられている。現在は、出入口の増設で、両妻側 1 階の空をそれぞれ一つずつ失っているが、その他は当時の面影を 残す。建設当初の姿は、両妻側において、 $1 \cdot 2$ 階に 2 つずつ。また 平側において、 $1 \cdot 2$ 階ともに 7 つずつ配置されていた。ただし、倉 庫西側 1 階は、 2 箇所の空位置を、前述の出入口としている。これ らの開口部における機能面について、後に詳述をおこなう。

なお、敷地内には別棟の土蔵 (土蔵造 地上 1 階建 建築面積 $\left.97.560 \mathrm{~m}^{2}\right)$ が現存する。洋菓子店として煉瓦倉庫が利用されていた 時は、工場兼住宅として改造、利用されていた。

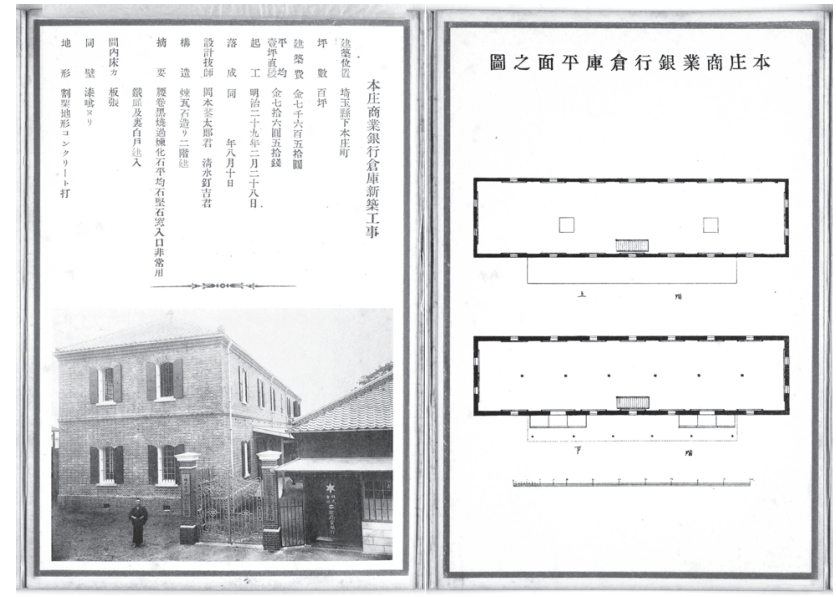

Fig. 1 「明治三十三年十二月製『清水方建築家屋撮影』」

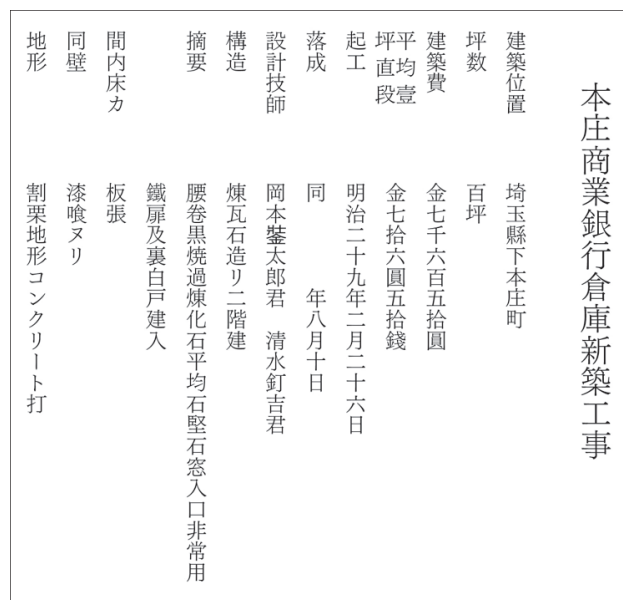

Fig. 2 建築概要箇所抜粋 


\subsection{3. 煉瓦の製造元}

本庄倉庫に用いられている煉瓦 の製造元については、既往研究では 倉庫の立地と建設年代から、埼玉県 深谷市上敷免に明治 $22(1889)$ 年に 工場を建設した日本煉瓦製造の製 品である可能性が高いとされてい

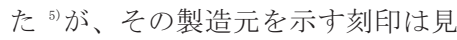
つかっていなかった。

今回、煉瓦の目地強度を調べるため に採取したサンプルコア(Fig. 2)か ら、煉瓦の製造元を示寸「上敷免」 刻印がなされている煉瓦が見つか った(Fig. 3)。このことから本庄倉庫 の煉瓦が、日本煉瓦製造上敷免工場 で焼成された煉瓦であることが判 明した。

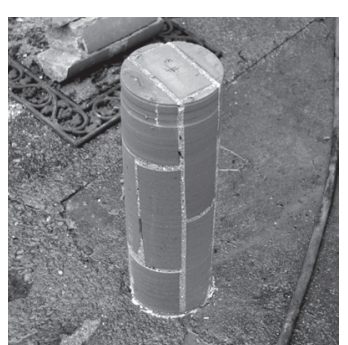

Fig. 2 サンプルコア

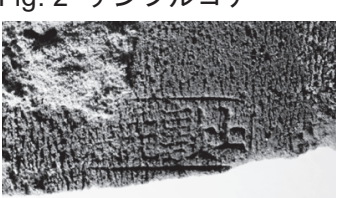

Fig. 3 今回発見された 上敷免の刻印

\subsection{4. 日本煉瓦製造の当時の状況}

既往研究によれば、本庄煉瓦倉庫が建設された当時は、日本煉瓦 製造株式会社の大口買い付け先だった碓水線（現在の信州本線）の 碓水トンネル工事がほぼ完了したため、その余剩煉瓦が一般市場に

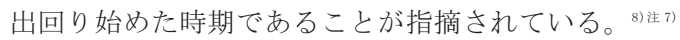

また、明治 28 (1895) 年の 5 月には、上敷免の工場と日本鉄道深 谷駅 (現在の高崎線深谷駅) を連絡する専用鉄道が敷設されている。 当時深谷駅と同線の本庄駅まで、煉瓦を鉄道での一貫輸送すること が可能であった。このような当時の煉瓦生産工場の状況も、本庄煉 瓦倉庫が、その構造に煉瓦造を用いて建設された要因の一つである と思われる。

\section{3. 本庄商業銀行の成立とその後の沿革}

\section{1. 絹産業の発展と本庄・肾玉の役割}

本庄煉瓦倉庫は、埼玉県本庄市を東西に貫く、中山道沿いに位置 寸る。明治維新後の日本において、殖産興業政策がとられるなか、 本庄も他地域の例に漏孔ず、商品としての藏生産が盛んとなった。 明治初期、本庄市、また現在は同市と合併した児玉町周辺が、藏の 一大生産となった ${ }^{9)}$ 。明治 6 年には、富岡に官営の富岡製系場が設 立されたが、初代製系場長をつとめた尾高惊忠は、明治 7 年に本庄 を訪れ䊀の買い入れを、諸井泉右衛門、坂上卯之助らに依頼をした。 彼らは、萰の買い付けのために藏市場を開善寺でひらく。このこと が契機となり本庄市に本格的な䋠市場が成立されることとなった ${ }^{10)}$ 日本の生糸生産は、一大産業へと発展していったが、その一方で 生産量に技術力がともなわず、粗製品が生み出される状況にあった。 当時、まだ製糸のための方法は、「座繰」による生産が主であった。 しかし、人の手をつかって糸を手繰るため、製品の質にばらつきが でや寸い。そこで、生系の安定した品質の担保と生産力を高めるた めに、器械製系が推し進められた。高崎線の開通により、信州資本 の大規模製糸業者が、本庄へ進出してきた。こうした業者は器械製 系を行い、本庄市の生産高を飛躍的に伸ばした。しかし、明治 30 年 ごろにおいては、大規模製紙業者は県外資本であり、いまだ小規模 な座繰製系工場が大部分を占めていた。 ${ }^{11}$

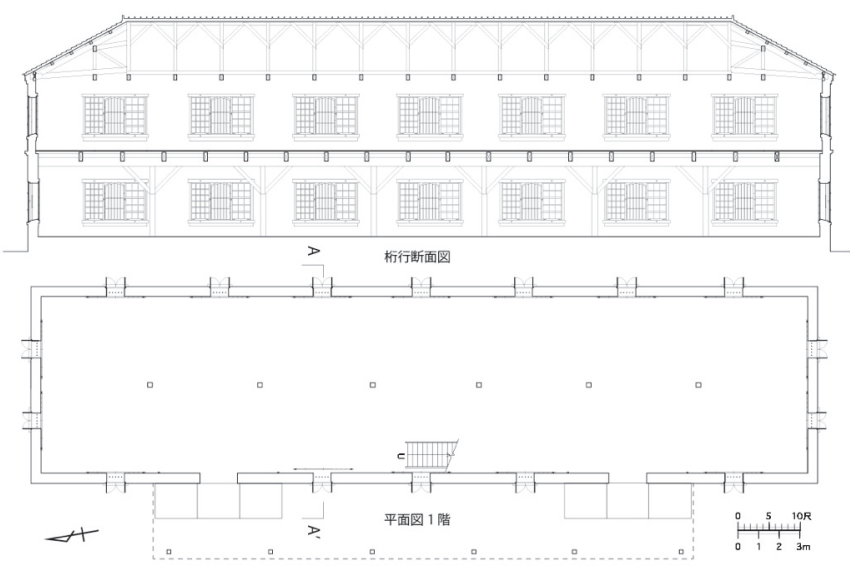

Fig. 4 本庄煉瓦倉庫 建設当初の平面・断面復元図 （実測調査と前掲『清水方建築家屋撮影』掲載図を基に作製）

\section{2. 民間製系業者の出現と貸付銀行の発生}

こうした富岡製糸場の創設に代表される、富国強兵策による、外 部経済と密接に結びついた蕾生産、製糸業といった絹産業の発展は、 上述のように本庄地域における経済規模を大きくさせた。こうした 経済発展を支えるために、明治 27 年に本庄ではじめての銀行とな る、「株式会社本庄商業銀行」が設立された。10)

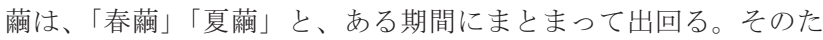
め、その短期間での原料の䒽の買い付けが、器械製系をおこなう「製 糸業者」にとって極めて重要である ${ }^{12)}$ 。そのため、本庄商業銀行は、 藏を担保として保管寸ることで、その購入資金の貸し付けをおこな った。その銀行の保管倉庫として、明治 29 年に建設されたのが本 稿で扱う、煉瓦倉庫である。

\section{3. 本庄商業銀行の設立}

本庄煉瓦倉庫は、商業銀行の設立後およそ 15 ケ月後に着工して いる。本庄商業銀行は、明治 27(1894)年に 12 月 1 日設立され、頭 取は後述する諸井孝次郎が務めた ${ }^{8}$. 0 本庄煉瓦竣工の明治 29(1896)

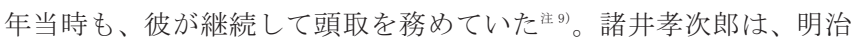
維新後に金融業を始めた父、諸井治郎から、明治 10(1877)年前後、 その地位を譲られ、そのことが本庄商業銀行設立にもつながってい ると考えられる。また、監查役の一人に諸井恒平 ${ }^{* 210)}$ が名を連初てい る。彼は本庄宿出身の実業家であり、渋沢栄一(1840-1931) とともに、 日本煉瓦製造を設立、また大正 12 年には秩父セメント株式会社を 設立した人物でもある。なお渋沢は、1887 年に清水店の相談役にも ついている。推測の域を出ないが、日本煉瓦製造株式会社の煉瓦が 使われたこと、また建設が清水店によることは、こうした渋沢との 近い関係性がその要因の一つとして考えられるだろう。

いずれにせよ、本庄商業銀行がこうした地域で有力な民間実業家 の支援を背景に成立されたことは、前述の県外資本勢力との相克が あったことを思わせる事実として重要である゙111。

\section{4. 絹産業を支える金融機関の位置づけ}

次に、こうした地方銀行自体が担保倉庫をもつことの意味を検討 したい。大正 4(1915)年に発行された「生系金融調查」(Table. 1. $)^{13)}$ には、製糸業者と銀行との資金の借り入れについて述べられている。 一時的な多額の現金を貸し付けることの出来る体制が、絹産業を発 展させる上での資金調達の重要な課題であった。 


\section{5. 担保倉庫の役割}

前述の通り、本庄商業銀行とその煉瓦倉庫の存在により、同銀行 は「銀行業」「倉庫業」の二つの側面を併せ持つ企業であったといえ る。こうした触の購入資金に、䋠を担保とした貸付をおこなう銀行 は、製系業が盛んな地域には、特別な存在ではなかった。そういっ た銀行は、「実際には䁷を製系家の家に保管をさせたり、委託した倉 庫業者に保管させた」。浊 ${ }^{12}$ また、諏訪の地方においては、後述する 通り無担保での貸付をおこなっていた事例などがあったようだ。12) なお、こうした鎘を担保とした取引は明治 20 年代より信州にまず 見られはじめ、座繰製系から器械製糸へと移り変わるとともに、群 馬県内の銀行でも見受けられる貸付の方法でもあった。そのなかで も前述した上毛倉庫 ”の手本ともなった国立第三十九銀行倉庫では、 製糸資金に関する貸付額の約八割が、この藏を担保とした貸付であ ったとされている。また、群馬県には現存する類似機能の遺構とし て、「安田銀行煉瓦倉庫」が挙げられる。(Fig. 5)

こうした、煉瓦倉庫は銀行が担保を手元に置くことができること、 また製系業者にとっては安全に、整えられた環境に藟を保管できる という双方のメリットがある。そして、こうした銀行倉庫は、安定 した高品質の生糸生産を実現させることに寄与し、結果として本庄 市の絹産業を発展させ、資本主義経済を支えていた。

\section{6. 小結 銀行が担保倉庫をもつ意味}

本庄煉瓦倉庫のように、特に銀行が担保倉庫を持つことの意味を 検討するのに、以下の一文を引き合いに出したい。ここでは、担保 の有無を述べた上で、特に、いまだ信用が確立されていない小規模 の製糸業者は、貸付を必要とする旨を述べている。また、そうした 担保として藏を預かることがあること、そうしたものは殺蛹、乾燥 した状態で収められていたことも読み取れる。そうした担保倉庫と して、挙げられている「銀行, 有スル倉庫」が存在する事例が、本 庄煉瓦倉庫であると考えられる。つまり、本庄市において、瞥を担 保として預かることの必要性として、中小規模の製糸業者が現れだ したこと、さらにそうした絹産業における現金需要がいよいよ盛ん になった状況であったといえる。

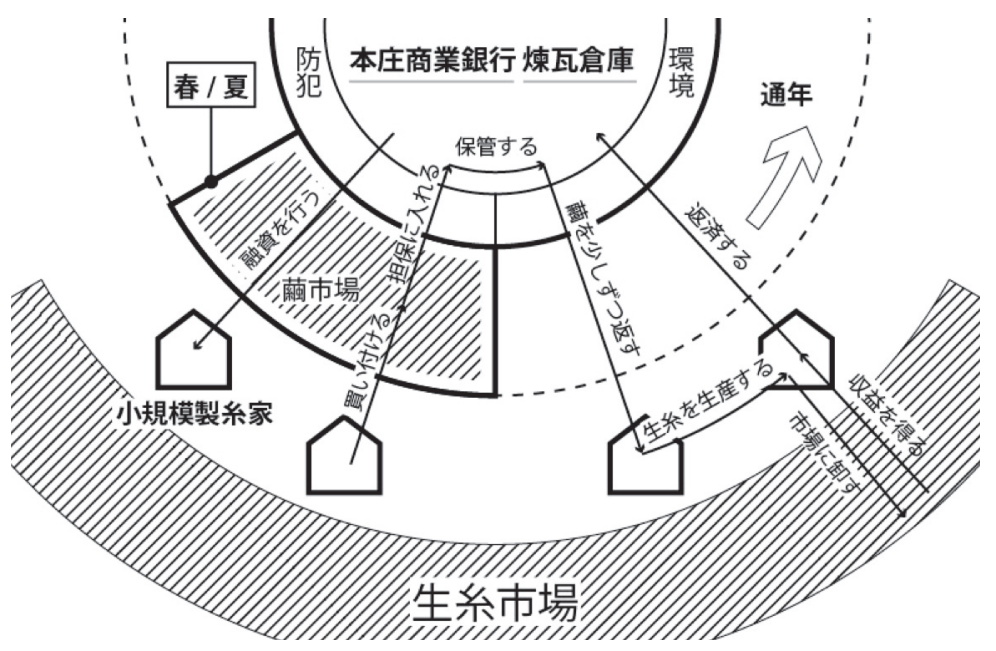

Fig. 5 䋨担保の仕組み
Table 1 「生糸金融調査」(1915) 一部抜粋 (なお、点線は筆者加筆)

\begin{tabular}{|c|c|c|c|}
\hline 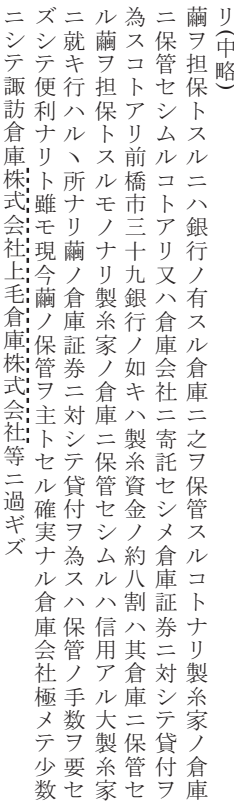 & 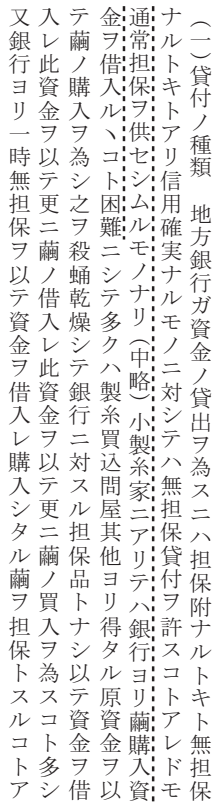 & 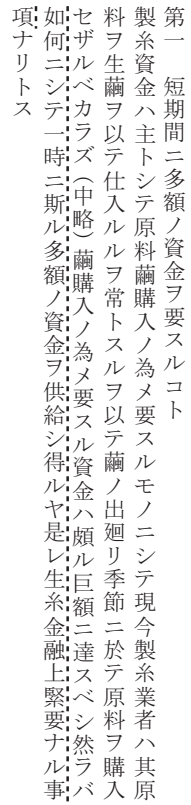 & 原 \\
\hline
\end{tabular}

また、ここでは、もう一点重要な記述が指摘できる。事例として 挙げられている前橋市の「第三十九銀行」と「上毛倉庫」は、後述 するが、いずれも清水店によるものである。当時技師長代行の中村 達太郎が担当したもので、上毛倉庫の設計に際しては模範とされた 倉庫でもある。この一文において、「䒽ノ保管ヨ主トセル確実ナル倉 庫会社」3) として、その機能の高さを保証する倉庫に、上毛倉庫が挙 げられていることは特筆に值する。同倉庫は、後述するが、本庄煉 瓦倉庫と同仕様、同設計者によって、同時期に建てられた倉庫であ る。清水店の技術力の高さとともに、本庄煉瓦倉庫もまたそうした 高い品質において建てられたことが予想される。

\section{4 藏の担保倉庫としての建築計画的特徵}

ここでは、貯蔵物である緇の保管要件を示した後、本 庄煉瓦倉庫の各所計画をみていく。それにより、荋をを担 保とする倉庫の基本的な性格についてまとめるもので ある。

\section{1. 藏貯蔵のための要件}

ここでは、䋠の長期貯蔵するために必要な要件、また 銀行の担保倉庫として必要な要件についてまとめる。掻 系業については様々な指導書が明治初期より発刊され ている。ここでは、倉庫の建造年と近しい、明治22(1889) 年に発刊された「實用乵桑書」(Table. 2$)^{14}$ における記述 を参照する。同書内の、「貯荋法」注 ${ }^{13}$ を参照する。特に 湿気と、そのための通風の必要性が説かれている。また、 通気性だけでなく、雨天時の密閉性もまた重要な要件で あることが読み取れる。

\section{2. 断面計画}

断面計画には、倉庫としての機能性とともに、前述藏 の保管庫としての湿気対策としての特徴が見受けられ る(Fig. 10)。以下に項目の列挙をおこなう。 
(1) 通気口（Fig. 6)

1 階、すべての空下部に通気口が存 在する。これには、鋳鉄製の金物が 嵌められている。

また、この通気口も、現在の路上面 より $300 \mathrm{~mm}$ ほどの高さの石組み より、さらに煉瓦 2 段の高さに位 置する。これにより、雨天時も湿気 の少ない空気を取り込んでいたも のと思われる。

(2) 1 階床高さ

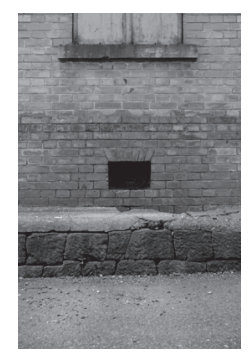

Fig. 6 通気口

(筆者撮影)
同通気口近くには、煉瓦が削られた痕跡が確認できる。また、 1 階中柱には、床組の根太の差し込まれていたとおもわれる 痕跡と概ね、同じ高さを取る。これは、1 階床組を支える木 部を煉瓦壁に持たせるための、「持ち出し積み」の痕跡と考え られる(Fig. 7 及び 8)。この痕跡高さは、地面高さより $600 \mathrm{~mm}$ の箇所であり。中柱痕跡との高さが一致するため、これが当 時の床高さであると考えられる。また、䇋工当時の写真を参 照すると、出入口付近にスロープが設置されているのが確認 でき、地面より、スロープを用いて、荷物の出し入れをして いたものと推察される。

(3) 天井高さ

床から梁下までの高さは $1 、 2$ 階ともに $3.2 \mathrm{~m}$ の高さがある。 2 階床には荷揚げ用の開口が 2 力所開けられており、1 階入 口から搬入された物品はこの荷揚げを用いて 2 階一搬入され ていたと考えられる。また、荷揚げ用の開口は、倉庫西側に 寄って取り付けられていた。これは出入口を考慮したもので あると指摘できる。

\section{3. 開口計画}

開口計画には、䋠の貯蔵庫という建築用途に必要な諸条件を満た 寸ための工夫が見受けられる。また、同時に銀行の倉庫としての機 能的な特徴も見受けられる。以下に、列挙を行う。

(1) 空は全ての方角に対して等間隔、かつ対照的に取り付けら

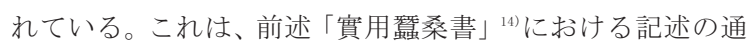
り、四方から風を取り込む必要性によるものと考えられる (Fig. 11)。 全ての空には網戸と、外面に漆喰が塗られた板戸が、取り
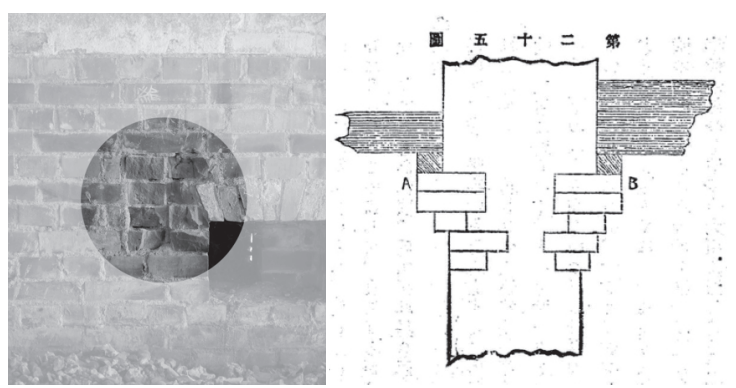

Fig. 7 (左) 持ち出し積みの痕跡と思われる箇所(筆者撮影)

Fig. 8 (右) 『建築設計便覧』(明治 42 年)に記載される 持ち出し積みに関する図版
Table 2 「実用蚕桑書」(1889)一部抜粋 (点線は筆者加筆)

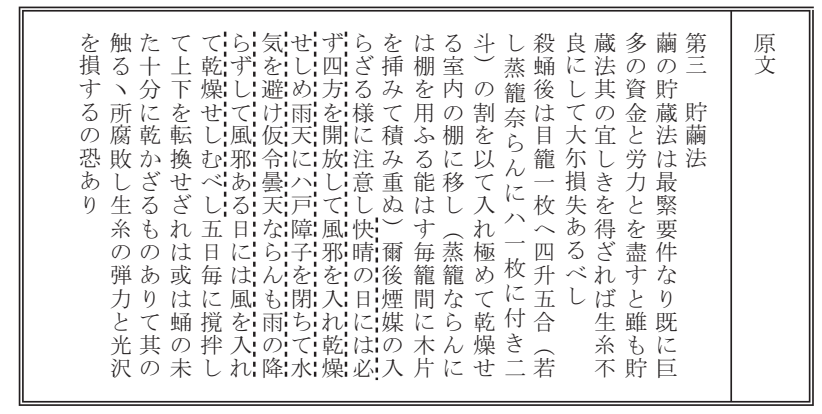

付けられている。これについては、現存しない 1 階出入口 の建具においても、その痕跡から同様の形式が取られてい たと思われる。

この開口部は、前述「實用望叠書」 ${ }^{13}$ に示されていた、天候 による調整を可能とした機構として考えられる。害虫を防 ぎながら、通気を確保する網戸は晴天時に、また漆喰板戸 は、雨天時の湿気の流入を防ぐ目的があると推察される。 (Fig. 9)

(3) 各空には外側に鉄扉が設けられている。内側には、現在数 カ所を残すのみであるが鉄柵が設けられている。鉄扉は、 先に示した漆喰の建具とともに防火のため、さらに鉄柵は、 銀行の倉庫としての防犯の目的をかなえるために取り付け られている。

\section{4 小結・開口計画にみる建築特性}

以上のような特徴は、本来土蔵などにおいても見受けられるもの である。本庄煉瓦倉庫は、その構造を土蔵から煉瓦造におきかえ、 必要な諸機能を残しながら計画されていることがわかる。これは、 2 節で述べたように本銀行のもつ「銀行業」「倉庫業」の両機能を充 足させるためであり、同時代の指導書との比較からも、そうした要 件を抑えていることも確認できた。
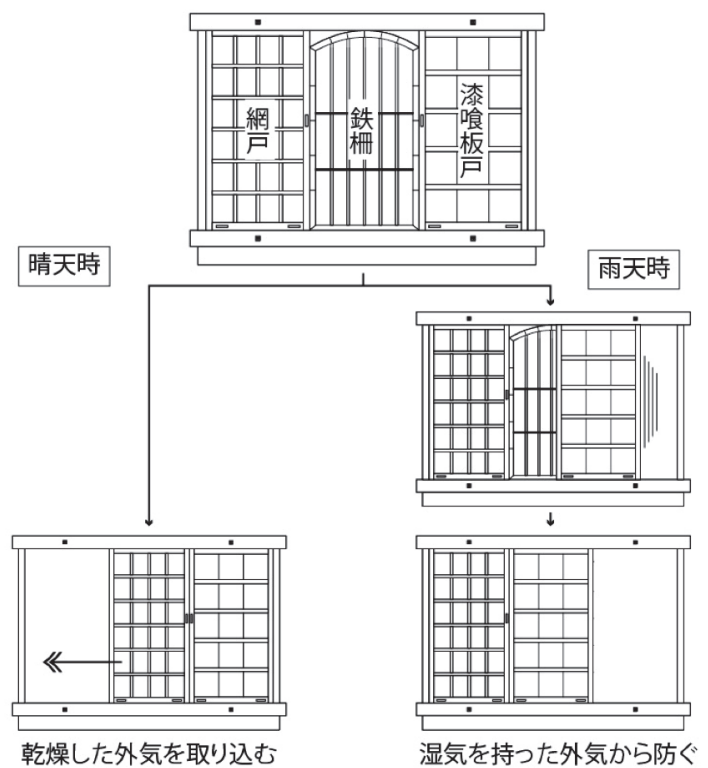

Fig. 9 建具のもつ環境調整機能(筆者作成) 


\section{5. 結論}

本稿は、埼玉県本庄市にのこる明治 29 年竣 工の旧本庄煉瓦倉庫煉瓦倉庫に関寸る報告の、 第 1 稿目として、まず建築概要と、設立の社会 的背景について、以下の報告をおこなった。

(1).これまで不明瞭であった、旧本庄商業銀 行煉瓦倉庫の竣工年や施工者等の情報 について、「明治三十三年十二月製『清水 方建築家屋撮影』」第 2 巻より、その確定 をおこなった。

(2). 実測調查を通した建築規模や平面・断面 についての、基礎情報について図面での 報告をおこなった。

(3). 明治中期から大正期にかけての本庄市 や前橋市における中小製糸業者の設立 という状況との関係の中で、発生した䊖 担保倉庫という、「銀行業」「倉庫業」の 二つの側面を併せ持つ地域的に特殊な ビルディングタイプについて整理をお こなった。

(4). 䋠を保管する倉庫として、年間を通じた 保管を可能とするための工夫について、 平面、断面計画と開口部の建具計画の観 点から、その特徵を考察した。また、そ れらは同時代の指導書である「実用虫桑 書」にも記載されるような、一般的な貯 藏法の必要条件が満たされていること も確認できた。

以上より、旧本庄商業銀行煉瓦倉庫は、殖産興業政策のなかで振 興された生系業の発展段階を示寸遺構であるといえる。こうした中 小の製系業者を支える銀行の存在が、埼玉県本庄市や、群馬県前橋 市における蔳取り引きを活性化させることとなり、引いては同地周 縁の養虫農家を潤すこととなった。地方都市の私設銀行として、十 分な設備投資がされたのも、こうした地域経済の要衝であったから

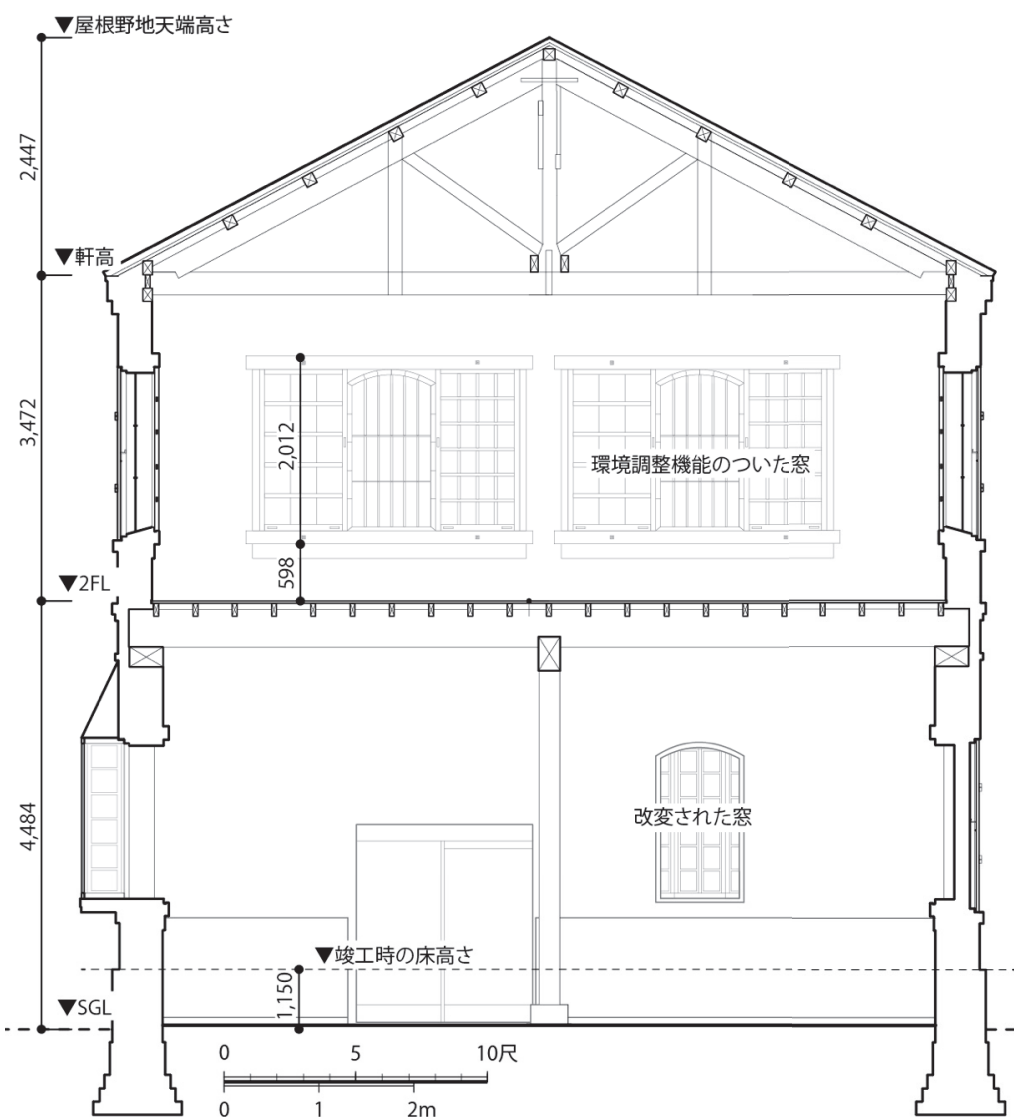

Fig. 10 本庄煉瓦倉庫 A-A'実測断面図

(平面図は Fig. 4 参照のこと)

こそと考えられるだろう。本稿では、本庄煉瓦倉庫の地域史的な特 徵への言及にとどめた。今後は、本庄煉瓦倉庫の施工における技術 面に着目し、報告をおこないたい。特に、本庄煉瓦倉庫が清水店の 主要建築物として記録がされているという事実から、当時の高い技 術力が投資されたものと考える。そのため、ひろく、同時代の類似 遺構や指導書との比較をもとに考察を加えていきたい。
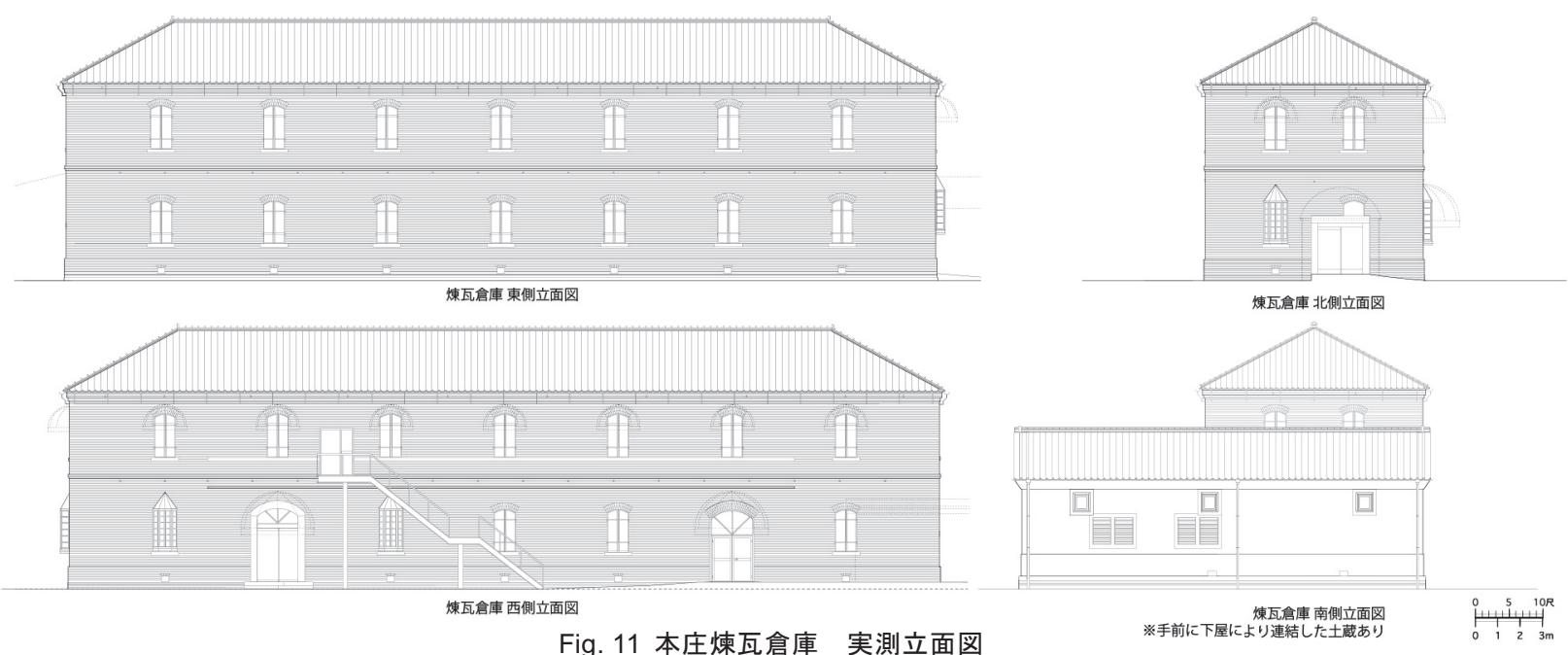


\section{参考文献}

1）埼玉県教育委員会, 埼玉県文化財保護協会：埼玉県明治建造物緊急調 查報告書 埼玉県明治建造物リスト, 埼玉県教育委員会, 埼玉県文化財保護 協会 1979

2) 日本建築学会：現存する明治洋風建築, 建築雑誌, 第 78 巻, 第 921 号, pp. 55-65, 1963. 01.

3) 関 建世, 日本建築学会, 明治建築小委員会 : 全国明治洋風建築リス卜 (主集 大正の建築), 建築雑誌, 第 85 巻, 第 1019 号, pp. 47-95, 1970. 01.

4) 日本建築学会：日本近代建築総覧 各地に遺る明治大正昭和の建物, 技 報堂出版 1980 .

5）太田 徹 ：群馬県前橋市と埼玉県深谷市に現存する煉瓦造担保倉庫の比 較・考察, 群馬県を中心とする煉瓦倉庫に関する調査, 日本建築学会大会 学術講演梗概集. F-2, 建築歴史・意匠, pp. 429-430, 2007. 07.

6) 松波 秀子：明治・大正期の建築作品集にみる清水組設計組織 (その 1), 清水建設研究報告, 第 89 巻, pp. 105-114, 2012. 01 .

7）上毛倉庫株式会社 編 ： 上毛倉庫七十年誌，上毛倉庫 1966 .

8）日本煉瓦製造株式会社社史編集委員会：日本煉瓦 100 年史，日本煉瓦製 造株式会社 1990 .

9）山口恵一郎：日本図誌大系, 朝倉書店 1972.

10）本庄市：本庄市史 3, 本庄市 1995 .

11）本庄市教育委員会：本庄市の養虫と製糸，養虫と絹のまち本庄，本庄 市教育委員会文化財保護課 2012 .

12）中林 真幸 : 虫糸業再編期における製系経営 - 経営発展と金融制度-, 経営史学, 第 35 巻, 第 1 号, pp. 1-29, 2000.

13）東京高等商業學校：生絲金融調査 調査部第七回報告, 東京高等商業學 校 1915 .

14）石井 研堂 : 實用䖯桑書, 有隣堂 1889 .

15）中村 達太郎：建築學階梯, 米倉屋書店 1888 .

16）二宮 峰男：生系貿易と金融, 同文館 1910 .

17）佐藤 宏亮, 後藤 春彦：近代虫糸業地域における都市形成過程, 本庄 町における近代化に伴う富裕層の活動と空間変容, 日本建築学会計画系論 文集，第 547 号，pp. 201-208，2001. 09.

18）公立 前橋工科大学大学院研究科 建築学専攻 石田敏明研究室：旧大 竹煉瓦蔵 一再生・利活用に関する調査研究報告書一, 2011.

19）前橋市教育委員会文化財保護課：旧大竹煉瓦蔵文化財調査報告書, 2006 .

20）前橋市都市景観審議会基本計画策定専門部会：前橋市都市景観形成近 代建造物 調査報告書, 1995 .

21）埼玉県社会経済総合調査会：埼玉県産業金融史研究報告書，埼玉県社 会経済総合調查会 1982 .

22）埼玉県立博物館：埼玉県の近代化遺産，近代化遺産総合調査報告書， 埼玉県教育委員会 1996 .

23）大久保 孝昭，千歩 修，長谷川直司，馬場明生，守明子，静村貴文，河 原利江：歴史的煉瓦造建築物の煉瓦モデュールの調査・分析手法の提案, 日本建築学会技術報告集，第 19 号，pp. 11-14，2004. 06.

24）太田 徹 ： 高崎市に現存する煉瓦倉庫についての基礎的検討, 群馬県 を中心とする煉瓦倉庫に関する調査・研究 4 , 日本建築学会関東支部研究 報告集 II，建築計画・都市計画・農村計画・建築経済・建築歴史・意匠, 第 77 号, pp. 433-436, 2007. 02.

25）太田 徹 ： 前橋市に残存する煉瓦倉庫についての基礎的検討，煉瓦倉 庫に関する調査・研究-1 (建築歴史・意匠), 日本建築学会関東支部研究報 告集 II, 建築計画 - 都市計画 - 農村計画 - 建築経済 · 建築歷史 · 意匠, 第 75 号, pp. 605-608, 2005. 02 .

26）太田 徹 ：上毛倉庫株式会社表町倉庫(前橋市)の設計者について，群 馬県を中心とする煉瓦倉庫に関する調査・研究-8, 日本建築学会大会学術 講演梗概集. F-2, 建築歴史・意匠, pp. 247-248, 2008. 07.

27）太田徹, 星 和彦：煉瓦造倉庫の外部意匠に関する一考察, 群馬県に おける煉瓦造倉庫に関寸る調査・研究，前橋工科大学研究紀要，第 12 号， pp. 28-35, 2009. 03.

28）太田 徹 ：群馬県における煉瓦造倉庫の再生・活用状況について 群馬 県を中心とする煉瓦造倉庫に関する調査・研究-10 (日本近代: 産業施設その 他, 建築歴史 ·意匠)，日本建築学会大会学術講演梗概集. F-2, 建築歴史 · 意匠, pp. 679-680,2010。 07.

29）小野英彦, 田島 三郎, 増田一裕, 福島 興嚴 : 目で見る本庄・児玉 の 100 年, 郷土出版社, 1999.

30）岡本 銺太郎：紡績工場の建築に就て, 建築雑誌, 第 23 巻, 第 269 号, pp. 191-195, 1909. 05 .

31）日本科学史学会：建築技術，第一法規出版， 1964 .

32）早川直瀬：製絲經濟論, 明文堂, 1913.

33）本庄市教育委員会 ：郷土のあゆみ，本庄の歴史，本庄市教育委員会， 1957.

34）松波 秀子：明治・大正期の建築作品集にみる清水組設計組織 (その 2),

清水建設研究報告, 第 89 巻, pp. 115-124，2012. 01 .

35）柴崎起三雄 : 本庄人物事典, 2003 .

36）清水 重敦：伊東忠太と「日本建築」保存（特集 維新と伝統），明治聖 徳記念学会紀要, 第 45 号, pp. 145-164, 2008. 11.

37）清水建設株式会社，清水建設百五十年史編纂委員会：清水建設百五十 年, 清水建設 1953 .

38）瀧 大吉：建築學講義録，建築書院 1896.

39）福井 覀啓，中谷 礼仁，本橋 仁，百野太陽，丸茂 友里：清水店施工 による煉瓦造担保倉庫の成立要因と建築的特質, 旧本庄商業銀行倉庫に関 する調查・研究 その 1 , 日本建築学会大会学術講演梗概集， F-2，建築歴 史・意匠, pp. 911-912, 2013.08.

40）諸井 恒平, 日本煉瓦製造株式会社：煉瓦要説 全, 博文館 (発売), 1902.

41）財団法人 文化財建造物保存技術教会：第 4 部 旧安田銀行担保倉庫 調査報告書，1994.

\section{注}

注 1）埼玉県本庄市より委託を受け、2012 年度より継続した研究を続けてい る。本稿でも報告をおこなう実測調查は、初年度に行ったものであり、そ れらは報告書(早稲田大学創造理工学研究科建築学専攻：旧本庄商業銀行 倉庫 一保存再生活用に関わる第一期報告書一, 早稲田大学, 2012.) として まとめられている。

注 2) これら情報については、2013 年度建築学会大会 (北海道)にて報告済 み。本稿においても基礎情報として報告内容を含み、さらに加筆を加える ものである。報告題目は以下のとおり。

福井 亜啓, 中谷 礼仁, 本橋 仁, 百野 太陽, 丸茂 友里 : 清水店施工によ る煉瓦造担保倉庫の成立要因と建築的特質：旧本庄商業銀行倉庫に関す る調査・研究 その 1 , 建築歴史・意匠, 日本建築学会学術講演梗概集, pp. 911912, 2013. 08.

注 3）調査は早稲田大学建築学科新谷眞人研究室、舆石直幸研究室、後藤春 彦研究室、中谷礼仁研究室、長谷見雄二研究室 (五十音順)にて実施した。 また、実測は 2012 年 2 月から 7 月にかけ実施。調査メンバーは、本橋仁・ 福井亜啓・百野太陽・ 丸茂友里（以上、中谷研究室）、山田俊亮・春田典 靖・本多裕作・小川祐季・若松直之（以上、新谷研究室）がおこなった。

注 4）今回の調査では、清水建設の協力を得て、同社所蔵の資料を利用。

注 5）現在の清水組にあたる同社の旧称であるが、複数の社名が併存する時 期にあたる。本稿では、松波秀子「明治・大正期の建築作品集にみる清水 組設計組織(その 1)」(2012)での表記方法を参照し、「清水店」として以降 記述をおこなうものとする。

注 6) 同写真帳より。清水建設所蔵

注 7）碓水トンネルの工事後、日本煉瓦製造は余剩煉瓦の販売に困難をきた し、生産規模を縮小寸る状況に陥っている。

注 8）他役員は、副頭取、宮下林平、取締役、境野伝七・ 戸谷八郎左衛門 · 松本文作

注 9） 1897 年当時の新聞記事における本庄商業銀行の記事において、頭取は 諸井孝次郎とされており、同社設立から、本庄煉瓦倉庫竣工まで変わりな く務めていたことを確認している。（株式会社本庄商業銀行 第五期営業 報告，朝日新聞，第朝刊巻，p. 8，1897.7月 17 日.)

注 10）本庄市において、諸井家は大きく三家にわかれる。諸井孝次郎は北諸 井家、諸井恒平は東諸井家であり、同族関係にあるとは言いがたい。

注 11） 本庄商業銀行の設立背景における諸井恒平、また渋沢栄一との関係 については、研究の課題として現在調査をおこなっている。埼玉県文書館 には、諸井三佐保文書という、東諸井家に関寸る資料が 2015 年より公開が されたことにより、より当時の状況が明瞭になると思われる。

注 12) 関武志 (青山学院大学教授)による科学研究費補助金採択課題「日本 資本主義の生成期における動産担保の機能的・史的分析」成果概要より 注 13) 同書 p. 167 


\section{APPEARANCE AND FUNCTION OF THE WAREHOUSE FOR COCOON AS COLLATERAL IN HONJO, SAITAMA}

A study of the old brick warehouse of the commercial bank of Honjo

Jin MOTOHASHI* and Norihito NAKATANI**

* Research Assoc., Faculty of Sciences and Engineering, Waseda Univ., M.Eng.

** Prof., Faculty of Sciences and Engineering, Waseda Univ., Dr.Eng.

This paper reports the basic research and the background of the Old Brick Warehouse of the Commercial Bank of Honjo, completed in 1896, Honjo city, Saitama prefecture. This paper, is the first of the follow-through repots on this architecture.

The results of this study are shown as bellow,

(1) By referring to "Photography on Buildings by the Shimizu-kata" (volume 2), we have found out that the Warehouse was designed by Sotaro OKAMOTO and Teikichi SHIMIZU, both company staff of Shimizu-ten and so it was built by the company in 1896 .

(2) By measuring the plans and sections, we reported basic information of this brick warehouse.

(3) This brick warehouse was built for cocoon collateral. By studying its backgrounds, it was made clear that this collateral had two functions, "banking" and "warehousing". From mid-Meiji era to Taisyo era, in Honjo and Maebashi city, many small and mid-sized businesses in the silk industry were established. These influenced cocoon collaterals as building-types to arise.

(4) The warehouse is capable in taking custody of cocoon throughout the year. Which was verified by examining the plan, section and joinery of opening sections. And, this mechanism fulfills the requisition in such as generalized methods marked in "Jitsuyo Sanso-syo" (Tamiji ISHII. Yuurindo, Tokyo, Japan. 1889) of Meiji era.

From the above, it could be said that this brick warehouse shows a stage of development in silk industry under the promotion of new industry in Japan. These banks which support the small and mid-sized companies of the silk industry has vitalized the cocoon market, enriched the silk-raising farmers in Honjo and Maebashi city and so forth. These private banks were keys to the regional economy and so this possibly could be the reason it had enough facility investments.

In this paper, we only refer to the features of this warehouse under regional history. But hereon, we will report on the technique of the brick-works and wood-works. Because this warehouse is thought to be built with a high level of technical capability of the mid-Meiji era, since it is recorded as one of the main buildings of Shimizu-ten. Thus, we plan to compare this warehouse to other brickworks and the manuals of the same period. 